КОНТРОЛЬ ДЕЯТЕЛЬНОСТИ ПОЛИЦИИ

Гришковец А.А.

\title{
ОБЩЕСТВЕННЫЙ СОВЕТ ПРИ МВД РОССИИ КАК ИНСТРУМЕНТ КОНТРОЛЯ ЗА ПОЛИЦИЕЙ
}

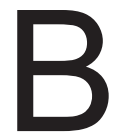

результате реформирования системы МВД России и принятия Федерального закона от 7 феевраля 2011 г. «О полиции» ${ }^{1}$ были значительно упрочены правовые основы общественного контроля за деятельностью полиции. Не умоляя важности данного обстоятельства, хотелось бы отметить, что в настоящее время и руководство МВД России рассматривает взаимодействие ведомства со структурами гражданского общества в качестве одного из приоритетов. Выступая на заседании расширенной коллегии МВД России 8 февраля 2013 г. и подводя итоги работы ведомства в 2012 г., министр внутренних дел Российской Федерации В.А.Колокольцев специально подчеркнул, «в истекшем году мы продолжали уделять особое внимание вопросам открытости своей работы, развитию всестороннего сотрудничества с институтами гражданского общества. Убежден, что важнейшим принципом и необходимым условием эффрективного выполнения задач в сорере внутренних дел является общественный контроль за деятельностью полиции со стороны общественных советов, созданных при Министерстве внутренних дел Российской Федерации и его территориальных органах. В качестве наблюдателей члены советов присутствуют на общественно-политических мероприятиях. Они оценивают,

${ }^{1}$ Собрание законодательства РФ. - 2011. - № 7. - Ст. 900. насколько соблюдаются права граждан и правомерны ли действия сотрудников полиции» ${ }^{2}$.

Действительно, основной акцент в развитии общественных формирований в сфере охраны общественного порядка в настоящее время сделан на создание общественных советов при государственных органах и, что особенно важно, наполнение их деятельности реальным, а не формальным содержанием. Очевидно, что мало создать соответствующий общественный совет, необходимо чтобы он мог, разумеется, в рамках действующего законодательства влиять на принятие управленческих решений, в том числе, по кадровым вопросам. На это обратил внимание в Послании Федеральному Собранию 2013 г. Президент Российской Федерации, где специально отметил, что как при федеральных, так и при региональных органах исполнительной власти необходимо создавать общественные советы. Конечно, во многих органах власти они уже есть, но не везде. И самое главное, специально подчеркнул глава государства, они не должны быть формальным придатком и декоративной структурой, а призваны выступать в роли экспертов, а порой и конструктивных оппонентов ведомств, быть активными участниками противодействия коррупции ${ }^{3}$. Такая организационная

\footnotetext{
2 http://президент.pф/news/17461

${ }^{3}$ Российская газета. - 2013. - 13 декабря.
} 
форма общественного контроля как общественные советы хорошо известна в нашей стране еще с советских времен, что неизменно отмечалось в специальной юридической литературе того периода ${ }^{4}$. В свете установок президентского послания нельзя не признать, что и в тот период данная форма страдала тем же недостатком, что и в постсоветской России, а именно тем, что общественный контроль был формальным, а сами общественные советы формировались под жестким контролем партийных и советских органов. Возможные инициативы «снизу» хотя формально-юридически и не запрещались, но в реальности были практически исключены.

Новый мощный импульс созданию общественных советов при федеральных органах исполнительной власти дал Федеральный закон от 4 апреля 2005 г. «Об общественной палате Российской Федерации» ${ }^{5}$. Правовую основу для образования общественных советов в системе органов внутренних дел составляют нормы ст. 20 данного Федерального закона и ч. 8 ст. 9 Федерального закона от 7 февраля 2011 г. «О полиции». Поскольку согласно ст. 32 Федерального конституционного закона от 17 декабря 1997 г. «О Правительстве Российской Федерации» российский Президент осуществляет руководство деятельностью федерального органа исполнительной власти, ведающего вопросами внутренних дел, то порядок образования общественного совета при МВД России согласно ч. 2 ст. 20 Федерального закона от 4 апреля 2005 г. «Об Общественной палате Российской Федерации» определяется главой государства. С этой целью изданы Указ Президента Российской Федерации от 23 мая 2011 года № 668 «Об общественных

\footnotetext{
${ }^{4}$ См.: Лазарева Н.С. О признаках и формах общественного контроля. Проблемы государства и права на современном этапе / Труды научных сотрудников и аспирантов. Вып. 7. - М.: Институт государства и права Академии наук СССР. 1973. - С. 78.

${ }^{5}$ Собрание законодательства РФ. - 2005. - № 15. - Ст. 1277.
}

советах при Министерстве внутренних дел Российской Федерации и его территориальных органах» ${ }^{6}$ и Указ Президента Российской Федерации от 28 июля 2011 года № 1027 «Об утверждении Положения об Общественном совете при Министерстве внутренних дел Российской Федерации» ${ }^{7}$.

Общественный совет при Министерстве внутренних дел Российской Федерации и общественные советы при территориальных органах Министерства внутренних дел Российской Федерации образуются в целях обеспечения согласования общественно значимых интересов граждан Российской Федерации, федеральных органов государственной власти, органов государственной власти субъектов Российской Федерации, органов местного самоуправления, общественных объединений, правозащитных, религиозных и иных организаций, в том числе профессиональных объединений предпринимателей, и решения наиболее важных вопросов деятельности органов внутренних дел Российской Федерации, в том числе полиции.

Основными задачами общественного совета являются:

а) привлечение граждан, общественных объединений и организаций к реализации государственной политики в сорере охраны общественного порядка, профилактики правонарушений, обеспечения общественной безопасности, а также содействие реализации государственной политики в сфрере противодействия преступности;

б) участие в разработке и рассмотрении концепций, программ, инициатив граждан, общественных объединений и организаций по наиболее актуальным вопросам деятельности органов внутренних дел;

в) участие в информировании граждан о деятельности органов внутренних дел, в том числе через средства массовой информации, и в публичном обсуждении во-

\footnotetext{
${ }^{6}$ Собрание законодательства РФ. - 2011. - № 22. - Ст. 3154.

${ }^{7}$ Собрание законодательства РФ. - 2011. - № 31. Ст. 4712.
} 


\section{Полицейская деятельность 4 • 2014}

просов, касающихся деятельности органов внутренних дел;

г) анализ мнения граждан о деятельности органов внутренних дел и доведение полученной в результате анализа обобщенной информации до руководителей соответствующих органов внутренних дел;

д) проведение общественной экспертизы проектов феедеральных законов и иных нормативных правовых актов по вопросам деятельности органов внутренних дел;

е) осуществление общественного контроля за деятельностью органов внутренних дел.

Таким образом, обеспечение общественного контроля за деятельностью органов внутренних дел выделено в качестве одной из основных, т.е., очевидно, приоритетных задач, решение которых как раз и призван обеспечить общественный совет.

Полномочия членов общественного совета закреплены в п. 7 Указа Президента Российской Федерации о 23 мая 2011 г. № 688. Они имеют право:

а) посещать без специального разрешения помещения, занимаемые органами внутренних дел, и также места принудительного содержания (например, изоляторы временного содержания) подозреваемых и обвиняемых в совершении преступления, задержанных лиц, лиц подвергнутых административному аресту, в порядке, предусмотренном Министром внутренних дел Российской Федерации;

б) знакомиться с обращениями граждан о нарушении их прав, свобод и законных интересов сотрудниками органов внутренних дел, а также с результатами рассмотрения таких обращений;

в) ходатайствовать перед соответствующими руководителями органов внутренних дел и контролирующих органов о проведении проверок соблюдения сотрудниками органов внутренних дел прав, свобод и законных интересов граждан, требований к служебному поведению, норм про- фрессиональной этики, принимать участие в таких проверках и знакомиться с их результатами;

г) участвовать в порядке, установленном Министром внутренних дел Российской Федерации, в работе совещаний, проводимых органами внутренних дел;

д) присутствовать в порядке, установленном Министром внутренних дел Российской Федерации, при проведении должностными лицами органов внутренних дел личного приема граждан.

Следует специально отметить, что общественный совет является лишь совещательным органом, решения которого носят рекомендательный характер. Вместе с тем, в той или иной степени учитывать позицию общественного совета или уж, по крайней мере, дать ее оценку при принятии соответствующего решения, думается, должно быть обязательным. В противном случае терялся бы смысл создания советов как структур, призванных обеспечить согласование применительно в деятельности органов внутренних дел, включая полицию, общественно значимых интересов с одной стороны и интересов государства - с другой стороны.

В основу формирования персонального состава общественного совета положен принцип добровольности участия в его деятельности граждан, членов общественных объединений и организаций. Согласно п. 6 Положения об Общественном совете при Министерстве внутренних дел Российской Федерации, утвержденного президентским Указом от 28 июля 2011 года № 1027, в состав Общественного совета входят председатель, заместители председателя, секретарь и члены Общественного совета. Количественный состав Общественного совета определяется Министром внутренних дел Российской Федерации, а его персональный состав также формируется главой данного ведомства, но на основе предложений граждан, представителей общественных 
объединений и организаций. Как видно механизм формирования общественного совета представляется достаточно демократичным, отвечающим его сути как некоего посредника между гражданами и обществом в целом и государством. По состоянию на 1 июля 2014 года численность Общественного совета при Министерстве внутренних дел Российской Федерации определена в количестве 38 членов и его персональный состав утверждены Приказом Министерства внутренних дел Российской Федерации от 5 ноября 2013 г. № 888 «Об утверждении состава Общественного совета при Министерстве внутренних дел Российской Федерации» ${ }^{8}$.

Одновременно была проделана значительная по объему работа по созданию общественных советов при территориальных органах МВД России на окружном, межрегиональном, региональном, районном уровне. Порядок их образования определен Приказом Министерства внутренних дел Российской Федерации от 15 августа 2011 г. № 939 «О мерах по реализации Указа Президента Российской Федерации» от 23 мая 2011 г. № 6689. Количественный состав общественного совета определяется руководителем территориального органа МВД России, и как правило, не должен превышать 30 человек. Члены общественного совета также имеют удостоверение, образец которого утвержден Приказом Министерства внутренних дел Российской Федерации от 7 октября 2011 г. № $1054^{10}$. Выдача удостоверений осуществляется теми территориальными органами внутренних дел, при которых образованы соответствующие общественные советы. Первое засе-

\footnotetext{
${ }^{8}$ Правовой акт опубликован не был.

${ }^{9}$ Правовой акт опубликован не был.

${ }^{10}$ Приказ Министерства внутренних дел Российской Федерации от 7 октября 2011 г. № 1054 «Об утверждении образца удостоверения члена общественного совета при территориальном органе Министерства внутренних дел Российской Федерации»// htt://mvd.ru/document/197962
}

дание общественного совета должно быть проведено не позднее чем через 30 дней после утверждения персонального состава общественного совета. Срок полномочий членов общественного совета истекает через два года после его первого заседания. По состоянию на 1 июля 2014 г. в состав общественных советов, образованных при территориальных органах внутренних дел входило 14639 членов, в том числе: на окружном уровне - 166 человек, на межрегиональном уровне - 141 человек, на региональном - 1776 человек, на районном - 12556 человек ${ }^{11}$.

Организация обеспечения деятельности Общественного совета при МВД России и оказание организационно-методической помощи общественным советам при территориальных органах МВД России на окружном, межрегиональном, региональном уровне возложены на Управление по взаимодействию с институтами гражданского общества и средствами массовой информации Министерства внутренних дел Российской Федерации, которое является самостоятельным подразделением центрального аппарата МВД России. Оно действует на основании Положения, утвержденного приказом Министерства внутренних дел Российской Федерации от 16 июня 2011 г. № $683^{12}$. Управление возглавляет А.В.Пилипчук, генерал-майор внутренней службы. Последнее вызывает определенное недоумение. Учитывая компетенцию управления, правильнее было бы, чтобы его возглавлял не сотрудник полиции, а лицо, находящееся на гражданской службе. Правовых препятствий для этого нет. Федеральный закон 27 мая 2003 г. № 58-Ф3 «О систе-

\footnotetext{
${ }^{11}$ CM.: htt://mvd.ru/mvd/sovet

${ }^{12}$ См.: Приказ Министерства внутренних дел Российской Федерации от 16 июня 2011 г. № 683 «Об утверждении положения об Управлении по взаимодействию с институтами гражданского общества и средствами массовой информации Министерства внутренних дел Российской Федерации» // Правовой акт официально опубликован не был.
} 
ме государственной службы Российской Федерации» (ч. 3. ст. 8) предусматривает, что в федеральном государственном органе могут учреждаться должности государственной службы различных видов.

Практика показывает, что членство в общественном совете достаточно престижно, т.к. оно позволяет устанавливать более тесные и, возможно даже не фрормальные личные контакты с руководством органов внутренних дел, включая полицию. И далеко не всегда мотивация в установлении таких контактов - это желание защищать общественные интересы, чем собственно и должны заниматься члены общественного совета. Данное обстоятельство нельзя не учитывать при формировании общественного совета. В его состав должны входить не только люди с формально безупречной репутацией, но, прежде всего те, кто своей предыдущей общественной деятельностью, активной, возможно даже где-то бескомпромиссной гражданской позицией доказал приверженность общественным интересам. В состав Общественного света в абсолютном большинстве вошли люди публичные, хорошо известные в стране и за рубежом общественные деятели, представители науки, образования и здравоохранения, средств массовой информации, религиозных конфессий. К примеру, председателем совета избран известный российский адвокат и общественный деятель А.Г.Кучерена, членами совета являются секретарь Общественной палаты Российской Федерации А.В.Бречалов, в недавнем прошлом президент Общероссийской общественной организации малого и среднего предпринимательства «ОПОРА РОССИИ», ректор Московского государственного юридического университета имени О.Е.Кутафина (МГЮА) В.В.Блажеев, председатель Комитета гражданских инициатив А.Л.Кудрин, известный экономист и государственный деятель, в недавнем прошлом заместитель Председателя Правительства Рос- сийской Федерации - министр финнансов Российской Федерации.

Не ставя под сомнение достоинства и авторитет действующего состава Общественного совета, все же хотелось бы отметить, что его члены люди очень занятые по основному месту своей профессиональной деятельности, перегруженные различной общественной работой. Достаточно привести один, по мнению автора, весьма показательный пример. Так, А.В.Кудрин помимо того, что он член Общественного совета при МВД России, также является деканом фракультета свободных искусств и наук СПБГУ, Председателем правления Фонда Кудрина по поддержке гражданских инициатив, Председателем Попечительского совета Института Гайдара, Членом президиума Экономического совета при Президенте, Председателем Попечительского совета Северного арктического федерального университета, Председателем Попечительского совета Фонда целевого капитала Европейского университета в Санкт-Петербурге, Членом Совета директоров Фонда Гайдара, Членом попечительского совета Государственного Эрмитажа, Главой Международного экспертного совета Всемирного экономического форума по России, Сопредседателем Попечительского совета Мариинского театра, Членом наблюдательного совета Сберегательного банка России ${ }^{13}$. Как говорится и прочее, прочее, прочее... Не правда ли впечатляет!

Следует сказать, что в ходе обсуждения в Государственной Думе проекта фредерального закона «Об основах общественного контроля в Российской Федерации», депутатом В.С.Золочевским (фракция ЛДПР) высказывалось предложение законодательно ограничить количество общественных структур, в которые может

\footnotetext{
13 Информация почерпнута с официального сайта Общественного совета при МВД России - www.os.mvd.ru в информационно-телекоммуникационной сети «Интернет».
} 
входить один человек ${ }^{14}$. Вряд ли с данным предложением можно согласиться, т.к. В случае его реализации будет без достаточных на то оснований ограничиваться право гражданина на участие в общественной деятельности. И потом, как в данном случае определить количественные характеристики? Тот же В.С.Золочевский полагает допустимым членство максимум в трех общественных структурах. Но это не более чем его субъективная оценка, не подкрепленная какими-либо убедительными аргументами. Думается, главным ограничителем в данном случае должна быть внутренняя позиция самого человека, который должен осознавать, что полноценная работа едва ли возможна при его членстве в многочисленных общественных структурах. В противном случае становится очевидным фракт его фрормального присутствия, да именно присутствия, а не работы в составе общественного совета, а значит - есть угроза репутации, которая для общественного деятеля исключительно важна.

В общем, участие в Общественном совете - едва ли не для всех его членов, в общем, еще одна дополнительная общественная нагрузка. Поэтому, заниматься, что называется, рутинной работой, скажем систематически, по личной инициативе посещать без специального разрешения те же места принудительного содержания подозреваемых и обвиняемых в совершении преступления, задержанных лиц, лиц, подвергнутых административному аресту, они вряд ли будут. А ведь именно в местах принудительного содержания, как показывает практика, случаются грубые нарушения прав и свобод человека и гражданина (прежде всего, унижение человеческого достоинства задержанных, неправомерное применение в отношении них мер фризиче-

\footnotetext{
${ }^{14}$ Государственная Дума. Стенограмма заседаний. Бюллетень № 165 (1403) 23 апреля 2014 г. / Издание Государственной Думы. С. 61.
}

ского воздействия и даже пыток). Думается, в состав общественного совета стоило бы в обязательном порядке включать хот бы 2-3 пусть и не слишком известных, но активных и заинтересованных членов правозащитных организаций, которые каждодневно и непосредственно контактируют как с гражданами и организациями, так и с правоохранительными органами, той же полицией. Именно такие, пусть, возможно, и неудобные члены Общественного совета позволили бы оживить его деятельность, сделать ее неформальной. К сожалению, именно этого добиться пока не удается. И здесь уместно вспомнить слова Министра внутренних дел Российской Федерации В.А.Колокольцева, который, выступая 4 декабря 2013 года на первом заседании Общественного совета в обновленном составе, отметил, что Министерству меньше всего нужен «декоративный» Общественный совет с полномочиями, прописанными лишь на бумаге ${ }^{15}$. Думается, еще предстоит проделать значительную по объему и продолжительную по времени работу, чтобы постепенно превратить общественные советы в действенный и реальный инструмент общественного контроля за деятельностью полиции и органов внутренних дел в целом. И в этом автор мог убедиться на личном примере, когда решил на практике познакомиться с деятельностью Общественного совета при МВД России. Как отмечалось выше, деятельность совета обеспечивает Управление по взаимодействию с институтами гражданского общества и средствами массовой информации Министерства внутренних дел Российской Федерации. Исходя из этого, автор направил 2 апреля 2014 г. обращение на имя Министра внутренних дел В.А.Колокольцева письмо (входящий номер № 3/16916 от 04.04.2014) с просьбой, в том числе, обеспечить его присутствие на заседании Общественного совета при МВД России.

\footnotetext{
15 http://os.mvd.ru/novosti/item/1386166/
} 


\section{Полицейская деятельность 4 • 2014}

В ответе из министерства, датированным 15 апреля 2014 г. (исходящий номер 15.04.2014 № 5/Ж-Г-33), но по неизвестным причинам полученным по почте только 23 мая 2014 г. рекомендовалось направить соответствующее письменное обращение в адрес общественного совета при МВД России. Правда, адрес, по которому можно направить такое обращение, почему-то не сообщался. В приемной МВД России, расположенной по адресу: Москва, ул. Садовая-Сухаревская, дом 11, во время личного приема автору сообщили адрес (117342, г. Москва, а/я 35) и даже телефон (8-800-250-85-00) Общественного совета при МВД России.

В течение июня 2014 г. автор, по крайней мере, на протяжении шести дней выборочно в начале, середине и в конце месяца в рабочие дни и в рабочее время неоднократно пытался дозвониться по указанному телефону. Однако всякий рез в телефонной трубке звучал один и тот же ответ: «номер временно не доступен». Вряд ли такое положение можно признать нормальным, отвечающим идее общественных советов как действенных и доступных для граждан инструментов контроля.

Общественный совет не должен быть своеобразным, в общем, фрактически элитарным «закрытым клубом» общественных деятелей, приближенных к министерству внутренних дел и его руководителю. Такой риск, исходя из практики прошлых лет, к сожалению, существует. Необходимо, чтобы каждый член общественного совета реально, причем активно и, что особенно важно, продуктивно работал исходя из той компетенции, которая определена законодательством для Общественного совета при МВД России. Этому, по мнению автора, способствовало бы ежемесячное размещение на официальном сайте совета персональных отчетов его членов о проделанной работе. На основе таких отчетов можно было бы периодически проводить селекцию членов Общественного совета, имея ввиду, выве- дение из его состава по результатам работы, скажем за квартал или полугодие, тех членов, которые реально не работали. Реализация данного предложения позволила бы и кандидатам в состав общественного совета более осмотрительно принимать решение о вхождении в общественный совет, где нужно будет реально работать. В противном случае может пострадать репутация, т.к. обществу, согражданам станет известно, что член общественного совета только числился, а не работал, и потому вполне закономерно был выведен из его состава.

Таким образом, персональные публичные отчеты членов общественных советов о проделанной в данном качестве работе будет стимулировать их реальную деятельность, и одновременно - выступать определенным сдерживающим фактором, ограничивающим членство одного человека во многих общественных структурах.

Нельзя сказать, что никакой информации пусть и не в форме отчета о работе членов Общественного совета при МВД России найти не удается. За период с декабря 2013 по июнь 2014 г. двое из них (М.В.Каннабих и Н.Б.Иванов) по одному разу каждый приняли участие в личном приеме граждан, который проводился в приемной министерства должностными лицами МВД России. Один член общественного совета та же М.В.Каннабих проверила работу полиции в Зубово-Полянском муниципальном районе Республики Мордовия. Данная информация размещена на официальном сайте совета. Чем в указанный период занимались другие члены общественного совета остается решительно неизвестно. Возможно, стоило бы предусмотреть обязательное и регулярное участие в приеме граждан для всех членов общественного совета, включая председателя, его заместителей и секретаря. График участия должен утверждаться на заседании Общественного совета при МВД России и размещаться на офи- 
циальном сайте совета. Участие в личном приеме позволит лучше понять проблемы заявителей, быть ближе к нуждам людей, тем более, если речь идет об их взаимоотношениях с полицией. Как показывает практика, риск нарушений конституционных прав и свобод человека и гражданина здесь остается достаточно высок. Кроме того, целесообразно также на регулярной основе предусмотреть посещение членами общественного совета мест принудительного содержания, находящихся в ведении органов внутренних дел.

Руководство Общественного совета при МВД России включает Председателя (А.Г.Кучерена), двух его заместителей (В.В.Блажеев и С.М.Миронюк) и секретаря (А.Г.Забелин). Также сфрормированы семь комиссий по направлениям деятельности (Комиссия по регламенту, организации деятельности Общественного совета при МВД России по взаимодействию с общественными советами при территориальных органах МВД России; Комиссия по общественному контролю за деятельностью органов внутренних дел; Комиссия по организации общественной экспертизе проектов нормативных правовых актов; Комиссия по укреплению духовнонравственных основ, совершенствованию работы по патриотическому и правовому воспитанию сотрудников органов внутренних дел; Комиссия по повышению информационной открытости МВД России, взаимодействию со средствами массовой информации и институтами гражданского общества; Комиссия по защите прав и законных интересов сотрудников органов внутренних дел, членов их семей и ветеранов МВД России; Комиссия по оказанию содействия привлечению квалифицированных кадров для службы в ОВД и информированию об особенностях службы). Председатель Общественного совета при МВД России, его заместители, секретарь совета, председатели комиссий образуют Президиум Общественного совета при
МВД России, который в период между его заседаниями совета, по сути, осуществляет его полномочия.

Согласно п. 2 ст. 8 Регламента Общественного совета при МВД России проводится по мере необходимости, но не реже одного раза в квартал. После обновления состава совета, которое произошло в ноябре 2013 года, по данным официального сайта совета по состоянию на 1 июля 2014 года состоялось два его заседания (4 декабря 2013 г. и 12 марта 2014 г.), а также одно заседания Президиума Совета (9 июня 06.2014 г.).

Членство в общественном совете предполагает безупречную репутацию и, что не менее важно, соблюдение определенных морально-этических норм, которые сформулированы в Кодексе этики членов общественных советов при Министерстве внутренних дел Российской Федерации и его территориальных органах (далее - Кодекс этики). Данный кодекс согласно ст. $34 \mathrm{Pe}-$ гламента Общественного совета при Министерстве внутренних дел Российской Федерации ${ }^{16} 16$ принимается самим Общественным советом. По состоянию на 1 марта 2014 года действует Регламент в редакции от 19 сентября 2013 года.

Информированность общественных советов о деятельности полиции и органов внутренних дел в целом - необходимое условие для их эффрективной деятельности, в том числе, деятельности контрольной. Получить необходимые сведения они могут путем заслушивания информации должностных лиц органов внутренних дел о деятельности органов внутренних дел по пресечению преступлений, охране общественного порядка, обеспечению общественной безопасности. Порядок заслушивания утвержден Приказом Министерства внутренних дел Российской Федерации от 23 мая 2012 г. № $534^{17}$.

\footnotetext{
${ }^{16} \mathrm{http}: / / \mathrm{mvd} . r u /$ document/1269120

${ }^{17}$ Правовой акт опубликован не был.
} 


\section{Полицейская деятельность 4 • 2014}

Предложение о заслушивании информации должностных лиц органов внутренних дел, включая должностных лиц полиции, на заседании общественного совета вносится председателем, членами общественного совета при формировании плана работы общественного совета или при подготовке проведения внепланового заседания общественного совета.

Перед принятием решения о проведении заслушивания информации должностного лица органа внутренних дел председатель общественного совета согласовывает тематику сроки и кандидатуру должностного лица, представляющего информацию с руководителем органа внутренних дел в котором проходит службу должностное лицо, планируемое к выступлению на заседании общественного совета. С таким подходом следует в полной мере согласиться. Очевидно, что заслушиваемое должностное лицо должно быть компетентным, детально разбираться в тех вопросах, по существу которых оно информирует членов общественного совета. Именно поэтому должностное лицо должно иметь достаточно времени чтобы подготовиться к выступлению, при необходимости запросить нужную информацию из структурных подразделений органов внутренних дел, провести консультации с теми сотрудниками, которые непосредственно занимаются вопросами, которые будут освещаться в выступлении.

Решение общественного совета о дате проведения, отмене, переносе заслушивания, замене кандидатуры должностного лица органа внутренних дел, представляющего информацию, доводится в течении десяти дней после принятия соответствующего решения в письменном виде до сведения данного должностного лица и руководителя органа внутренних дел, в котором проходит службу должностное лицо.

Заслушивание информации должностного лица органа внутренних дел на заседании общественного совета проводит- ся в форме выступления должностного лица органа внутренних дел в соответствии с повесткой для заседания общественного совета, утвержденной председателем общественного совета. Как видно какое-либо обсуждение заслушенной информации должностного лица с его непосредственным участием, возможность задать вопросы и получить на них аргументированные ответы, не предусмотрены. Думается, такое положение снижает ценность и практическую значимость заслушивания должностного лица органа внутренних дел.

По результатам заслушивания информации должностного лица органа внутренних дел общественный совет:

- выносит предложение руководителю органа внутренних дел по совершенствованию деятельности органа внутренних дел, информация о котором заслушана общественным советом;

- ходатайствует перед руководителем органа внутренних дел о проведении проверок сотрудниками органа внутренних дел прав и свобод граждан, законности, выполнения обязанностей, возложенных на них Федеральным законом от 7 февраля 2011 г. «О полиции», а также требований к служебному поведению и норм профессиональной этики.

Решение общественного совета направляется для рассмотрения руководителю органа внутренних дел, при котором этот общественный совет создан. Решение общественного совета рассматривается в течение месяца со дня его поступления в соответствующий орган внутренних дел. По результатам рассмотрения в общественный совет направляется информация. Таким образом, хотя решение общественного совета не является обязательным для соответствующего руководителя органа внутренних дел, тем не менее оно подлежит обязательному рассмотрению и на него в установленный срок должна быть дана информация, содержащая, 
очевидно, аргументированные ответ, в том числе о принятых мерах, например дисциплинарного характера, по существу вопросов, обозначенных в обращении общественного совета.

Представляется обоснованным расширить круг вопросов, которые могут быть заслушаны общественными советами, дополнив его также информацией о кадровой политике, проводимой в соответствующем органе внутренних дел. Как известно, именно от качества кадрового состава, его профессиональных, деловых, личностных качеств в решающей степени зависит эфффективность деятельности полиции и органов внутренних дел в целом по пресечению преступлений, охране общественного порядка, обеспечению общественной безопасности и профилактике правонарушений. Крайне значимым являются контрольные полномочия членов общественных в сфере обеспечения прав и свобод человека и гражданина тех лиц, которые находятся в местах принудительного содержания (лица, подвергнутые административному задержанию и административному аресту; лица, задержанные по подозрению в совершении преступлений, к которым применена мера пресечения в виде заключения под стражу; несовершеннолетние, находящиеся в центрах временного содержания для несовершеннолетних). Практика, в том числе резонансные сообщения в средствах массовой информации свидетельствуют, что имеют место далеко не единичные случаи нарушения прав человека в местах принудительного содержания, в том числе тех из них, что находятся в ведении органов внутренних дел. Достаточно вспомнить имевший большой общественный резонанс случай применения пыток в отношении задержанного, повлекших его смерть, в отделе полиции «Дальний» в г. Казани, Республика Татарстан в марте 2012 г. Закрытый судебный процесс по данному делу завершился в июне 2014 г. Десять бывших полицейских получили от двух лет колонии-поселения до пятнадцати лет колонии строгого режима. Наибольший срок суд назначил бывшему замначальника отдела уголовного розыска Алмазу Василову, на счету которого, по данным следствия, наибольшее число преступных эпизодов, в том числе зверские истязания казанца, скончавшегося от полученных в отделе полиции «Дальний» травм $^{18}$. Поэтому обеспечение эффрективного общественного контроля за обстановкой в местах принудительного содержания представляется крайне важным и актуальным.

Исходя из компетенции органов внутренних дел, в их ведении находится места принудительного содержания (специальные помещения дежурных частей для содержания лиц, задержанных полицией ${ }^{19}$; изоляторы временного содержания подозреваемых и обвиняемых органов внутренних дел ${ }^{20}$; центры временного содержания несовершеннолетних правонарушителей органов внутренних дел $\left.{ }^{21}\right)$. Так, согласно данным, приведенным в государственной программе Российской Федерации «Обеспечение общественного порядка и противодействие преступности» ${ }^{22}$, в органах

\footnotetext{
18 См.: Истязания в полиции измерили сроками // Коммерсантъ. - 2014. - 17 июня.

${ }^{19}$ См.: Приказ Министерства внутренних дел Российской Федерации от 30 апреля 2012 г. № 389 «Об утверждении Наставления о порядке исполнения обязанностей и реализации прав полиции в дежурной части территориального органа МВД России после доставления граждан» // Российская газета. - 2012. - 11 июля.

${ }^{20}$ См.: Приказ Министерства внутренних дел Российской Федерации от 22 апреля 2005 г. № 950 «Об утверждении Правил внутреннего распорядка изоляторов временного содержания подозреваемых и обвиняемых органов внутренних дел» // Бюллетень нормативных актов федеральных органов исполнительной власти. - 2005. - № 51.

${ }^{21}$ См.: Приказ Министерства внутренних дел Российской Федерации от 1 сентября 2012 г. № 839 «О совершенствовании деятельности центров временного содержания для несовершеннолетних правонарушителей» // Российская газета. 2012. 17 декабря.

${ }^{22}$ См.: Распоряжение Правительства Российской Федерации от 6 марта 2013 г. № 313-р // С3 РФ. - 2013. - № 11. - Ст. 1145.
} 


\section{Полицейская деятельность 4 • 2014}

внутренних дел Российской Федерации фрункционировало 4 тыс. дежурных частей и 1750 изоляторов временного содержания подозреваемых и обвиняемых с лимитом наполнения 35,4 тыс. мест.

Пункт 7 Указа Президента Российской Федерации от 23 мая 2011 года № 668 специально предусматривает право членов общественных советов при МВД России и его территориальных органах посещать места принудительного содержания подозреваемых и обвиняемых в совершении преступления, задержанных лиц, лиц подвергнутых административному аресту. Правила посещения определены Приказом МВД России от 2 августа 2012 г. № $754^{23}$.

Посещать места принудительного содержания без специального разрешения вправе члены Общественного совет при МВД России и члены общественных советов при территориальных органах МВД России. При этом право последних ограничено. Они могут посещать только те места принудительного содержания, которые подведомственны соответствующим территориальным органам МВД России.

Посещение мест принудительного содержания осуществляется в соответствии с правилами их внутреннего распорядка. О планируемом посещении мест принудительного с указанием даты и намеченных мест посещения уведомляются:

председателем Общественного совета при МВД России (лицом его замещающим) - Министр внутренних дел Российской Федерации и начальник органа внутренних дел, места принудительного содержания, посещение которого планируется;

\footnotetext{
${ }^{23}$ См.: Приказ Министерства внутренних дел Российской Федерации от 2 августа 2012 г. № 754 «О порядке посещения без специального разрешения членами общественных советов при Министерстве внутренних дел Российской Федерации и его территориальных органах помещений, занимаемых органами внутренних дел, а также мест принудительного содержания подозреваемых и обвиняемых в совершении преступления, задержанных лиц, лиц, подвергнутых административному аресту» // Российская газета. - 2012. - 21 декабря.
}

председателем общественного совета при территориальном органе МВД России (лицом его замещающим) - начальник территориального органа МВД России, при котором образован соответствующий совет, а также начальник подчиненного территориального органа МВД России, места принудительного содержания, посещение которого планируется.

Таким образом, хотя прямо об этом и не говорится, уведомлять о планируемом посещении член общественного совете должен заблаговременно, с чем, в общем, трудно согласиться. Приходится признать, что Правила посещения мест принудительного содержания не определяют в какой именно форме письменной или устной происходит соответствующее уведомление. Кроме того, представляется вряд ли правильным осуществлять посещение мест принудительного содержания фактически только по предварительному уведомлению. В этом случае, очевидно, отсутствует эфффект внезапности, а потому у должностных лиц органов внутренних дел, полиции посещаемого места принудительного содержания появляется возможность основательно к нему подготовиться, скрыть возможные недостатки, провести работу с контингентом, содержащемся в месте принудительного содержания, направленную на то, чтобы не допустить жалоб и других обращений негативно характеризующих деятельность должностных лиц места принудительного содержания. Думается, требование обязательного уведомления в данном случае следовало бы отменить, предоставив членам общественных советов при МВД России и его территориальных органах право посещать места принудительного содержания органов внутренних дел без обязательного уведомления и в любое время суток, а не только в соответствии с правилами внутреннего распорядка места принудительного содержания, т.к. в последнем случае посещение, по сути, 
ограничивается только дневным временем. Напротив, именно в ночное время риск нарушения прав и свобод лиц, находящихся в местах принудительного содержания (например, незаконный ночной допрос, лишающий человека нормального сна), оказывается заметно выше.

Подтверждением полномочий члена общественного является удостоверение члена общественного совета установленного образца, которое он предъявляет вместе с документом удостоверяющим личность гражданина Российской федерации при посещении помещении мест принудительного содержания.

При посещении места принудительного содержания члены общественных советов подчиняются законным требованиям начальника места, направленным на соблюдение внутреннего распорядка места принудительного содержания. Не допускается вмешательство членов общественных советов в оперативно-розыскную деятельность, уголовно-процессуальную деятельность и производство по делам об административных правонарушения, а также нарушение правил внутреннего распорядка места принудительного содержания. В случае нарушения правил внутреннего распорядка места принудительного содержания, невыполнения законных требований сотрудников органов внутренних дел должностное лицо, сопровождающее членов общественных советов, предупреждает их о недопустимости совершения указанных действий. В случае повторного нарушения посещение прерывается по решению начальника места принудительного содержания. Как видно, член общественного совета, посещающий место принудительного содержания, должен строго придерживаться его внутреннего распорядка. Какие либо отступления о него недопустимы и должны решительно пресекаться соответствующими должностными лицами органов внутренних дел.
Кроме того, Правила посещения мест принудительного содержания не определяют какими правами наделен член общественного совета. Ограничивается ли его право только пассивным наблюдением за тем, что происходит в месте принудительного содержания, либо член общественного совета может реализовывать в ходе посещения и другие полномочия, как то: беседовать с лицами, находящимися в месте принудительного содержания, принимать от них письменные и устные заявления, в том числе жалобы на нарушение их прав, обращать внимание начальника места принудительного содержания на недостатки в работе, например, плохое санитарное состояние или недостаточное освещение в помещении места принудительного содержания. В пункте 7 Указа Президента Российской Федерации от 23 мая 2011 г. № 668 «Об общественных советах при Министерстве внутренних дел Российской Федерации и его территориальных органах», где определены права членов общественных советов, и Приказ МВД России от 2 августа 2012 года № 754, которым в соответствии с данным пунктом президентского указа утвержден Порядок посещения членами общественных советов мест принудительного содержания на данный вопрос, к сожалению, ответа не дают.

Безусловно признавая значимость общественных советов, созданных при МВД России и его территориальных органах для обеспечения общественного контроля за полицией, вместе с тем хотелось бы отметить, что порядок их фрормирования, и это фрактически признал глава государства в Послании Федеральному Собранию 2013 г., далеко не безупречен, а сами общественные советы на практике пока, к сожалению, так и не стали реальным и действенным инструментом общественного контроля, в чем автор мог отчасти убедиться и на личном примере.

Поэтому определенный скепсис вызывают слова Министра внутренних дел 


\section{Полицейская деятельность 4 • 2014}

Российской Федерации В.А.Колокольцева, который, выступая на расширенном заседании Коллегии МВД России с участием Президента Российской Федерации 21 марта 2014 г., отрапортовал Главе государства: «Целенаправленные меры предпринимались по усилению общественного контроля за деятельностью органов внутренних дел. Ведется конструктивный диалог с институтами гражданского общества. Обновлены составы общественных советов $^{24}$. Персоналии, конечно, обновлены, но суть, по мнению автора, к сожалению, остается прежней. Общественные советы пока многом продолжают быть «потемкинскими деревнями», декорацией, призванной продемонстрировать как внутри страны, так и, возможно даже в большей степени, зарубежной аудитории смягчение доставшейся в наследство демократической России советской репрессивной правоохранительной системы, основу основ которой составляет полиция и органы внутренних дел в целом. Тем не менее, ее трансформация возможна. В значительной степени она зависит от гражданской активности людей, которые должны преодолеть глубоко укоренившийся в сознании со времен советского тоталитарного государства и вакханалии как криминального, так и ми- лицейского насилия 90-х годов прошлого века страх перед правоохранительной системой, той же полицией, боязнь вступить в, казалось бы, неравную борьбу с этим своеобразным библейским великаном Голиафом за безусловное соблюдение принципа законности. И эта гражданская активность нарастает.

Данное обстоятельство подтверждает и секретарь Общественной палаты Российской Федерации, член Общественного совета при МВД России А.В.Бречалов, который отметил, что активность граждан по проекту «За честные закупки» беспрецедентна ${ }^{25}$. Правда, следует оговориться, в данном случае речь идет об интернет-активности, но в любом случае это свидетельствует о гражданской активности людей, а значит - о развитии и укреплении в России структур гражданского общества, которые оказывают реальное влияние на происходящие в стране социальные процессы. Вместе с тем, говорить об установлении взаимно ответственных партнерских отношений между государством и гражданским обществом пока явно преждевременно. И ситуация с общественными советами в системе МВД России служит тому достаточно убедительным подтверждением.

\section{Библиография:}

1. Господин антинавальный // Московский комсомолец. - 2014. - 23 июня.

2. Лазарева Н.С. О признаках и фрормах общественного контроля. Проблемы государства и права на современном этапе / Труды научных сотрудников и аспирантов. Вып. 7. - М.: Институт государства и права Академии наук СССР. 1973. - С. 78.

3. Выступление главы МВД России на расширенном заседании коллегии Министерства 21 марта 2014 г. // HTTP://MVD.RU/KOLLEGIYA_03_2014

4. Овчинников Н.А. Административный контроль как способ обеспечения законности в служебной деятельности органов внутренних дел. // Административное и муниципальное право. - 2011. - 3. - С. 36 - 43.

\footnotetext{
${ }^{24}$ См.: Выступление главы МВД России на расширенном заседании коллегии Министерства 21 марта 2014 г. // HTTP://MVD.RU/KOLLEGIYA_03_2014
}

${ }^{25}$ Господин антинавальный // Московский комсомолец. 2014. - 23 июня. 
5. Овчинников Н.А. О содержании административно-правового механизма обеспечения законности в системе МВД России // Административное и муниципальное право. 2011. - 11. - С. $33-38$.

6. К.А. Кареева-Попелковская Акты реализации мер административного пресечения в деятельности полиции // Административное и муниципальное право. - 2011. - 12. С. $39-48$.

7. Новоселов С.А., Трунцевский Ю.В. Повышение эффективности предупреждения преступлений и иных правонарушений, коррупционной направленности, совершаемых сотрудниками ГИБДД, как условие организации дальнейшего реформирования ОВД РФ согласно Дорожной карте // Административное и муниципальное право. - 2013. 4. - C. 321 - 326. DOI: 10.7256/1999-2807.2013.04.3.

8. Трунцевский Ю.В., Новоселов С.А. Повышение эффективности предупреждения преступлений и иных правонарушений, коррупционной направленности, совершаемых сотрудниками ГИБДД, как условие организации дальнейшего реформирования ОВД РФ согласно Дорожной карте // NB: Административное право и практика администрирования. - 2013. - 5. - C. 45 - 61. DOI: 10.7256/2306-9945.2013.5.8843. URL: http:// www.e-notabene.ru/al/article_8843.html

9. Горин Е.В. Административно-правовое регулирование управления вневедомственной охраной // Полицейская деятельность. - 2013. - 4. - C. 268 - 275. DOI: 10.7256/22221964.2013.4.9475.

10. М.Ф. Дёмина Административно-юрисдикционная и контрольная деятельность в сфере осуществления частной детективной и охранной деятельности // Административное и муниципальное право. - 2011. - 12. - С. $64-68$.

\section{References (transliteration):}

1. Lazareva N.S. O priznakakh i formakh obshchestvennogo kontrolya. Problemy gosudarstva i prava na sovremennom etape / Trudy nauchnykh sotrudnikov i aspirantov. Vyp. 7. M.: Institut gosudarstva i prava Akademii nauk SSSR. 1973. - S. 78.

2. Ovchinnikov N.A. Administrativnyi kontrol' kak sposob obespecheniya zakonnosti v sluzhebnoi deyatel'nosti organov vnutrennikh del. // Administrativnoe i munitsipal'noe pravo. $-2011 .-3 .-$ C. $36-43$.

3. Ovchinnikov N.A. O soderzhanii administrativno-pravovogo mekhanizma obespecheniya zakonnosti v sisteme MVD Rossii // Administrativnoe i munitsipal'noe pravo. - 2011. - 11. - C. $33-38$.

4. K.A. Kareeva-Popelkovskaya Akty realizatsii mer administrativnogo presecheniya v deyatel'nosti politsii // Administrativnoe i munitsipal'noe pravo. - 2011. - 12 - C. $39-48$.

5. Novoselov S.A., Truntsevskii Yu.V. Povyshenie effektivnosti preduprezhdeniya prestuplenii i inykh pravonarushenii, korruptsionnoi napravlennosti, sovershaemykh sotrudnikami GIBDD, kak uslovie organizatsii dal'neishego reformirovaniya OVD RF soglasno Dorozhnoi karte // Administrativnoe i munitsipal'noe pravo. - 2013. - 4. - C. 321 - 326. DOI: 10.7256/1999-2807.2013.04.3.

6. Truntsevskii Yu.V., Novoselov S.A. Povyshenie effektivnosti preduprezhdeniya prestuplenii i inykh pravonarushenii, korruptsionnoi napravlennosti, sovershaemykh sotrudnikami GIBDD, kak uslovie organizatsii dal'neishego reformirovaniya OVD RF soglasno Dorozhnoi karte // NB: Administrativnoe pravo i praktika administrirovaniya. - 2013. - 5. - 
C. 45 - 61. DOI: 10.7256/2306-9945.2013.5.8843. URL: http://www.e-notabene.ru/al/article_8843.html

7. Gorin E.V. Administrativno-pravovoe regulirovanie upravleniya vnevedomstvennoi okhranoi // Politseiskaya deyatel'nost'. - 2013. - 4. - C. 268 - 275. DOI: 10.7256/22221964.2013.4.9475.

8. M.F. Demina Administrativno-yurisdiktsionnaya i kontrol'naya deyatel'nost' $v$ sfere osushchestvleniya chastnoi detektivnoi i okhrannoi deyatel'nosti // Administrativnoe i munitsipal'noe pravo. - 2011. - 12. - C. $64-68$. 